\title{
Reduced Diversity and Relative Abundance of Terrestrial Snails in a Red Pine Plantation Compared with a Surrounding Northern Red Oak - Large-toothed Aspen Woods
}

\author{
Paul M. Catling ${ }^{1,2}$ and Brenda KostiuK ${ }^{1}$ \\ ${ }^{1} 170$ Sanford Ave., Ottawa, Ontario K2C 0E9 Canada \\ ${ }^{2}$ Corresponding author: catlingpm@gmail.com
}

Catling, Paul M., and Brenda Kostiuk. 2017. Reduced diversity and relative abundance of terrestrial snails in a Red Pine plantation compared with a surrounding Northern Red Oak - Large-toothed Aspen woods. Canadian Field-Naturalist 131(2): 128132. https://doi.org/10.22621/cfn.v131i2.1982

A Red Pine (Pinus resinosa Aiton) plantation and adjacent Northern Red Oak (Quercus rubra L.) - Large-toothed Aspen (Populus grandidentata Michx.) woods, both of which developed from a savannah scrub beginning approximately 60 years ago, were compared with regard to terrestrial snail diversity and abundance. The comparison involved a 30-minute search of ten 1-m² quadrats at ten sites in each habitat. In the Northern Red Oak - Large-toothed Aspen woodland, 13 species and 661 individuals were recorded, whereas, in the Red Pine plantation, six species and 24 individuals were recorded. In the Northern Red Oak Large-toothed Aspen woodland, the most characteristic and abundant species was Novisuccinea ovalis (Say, 1817), which was present in 74 of the 100 quadrats and was represented by 460 individuals. In the pine plantation, the most common species was Zonitoides arboreus (Say, 1816), which was present in 16 quadrats and was represented by 17 individuals. This species was the second most common in the Northern Red Oak - Large-toothed Aspen woodland where 70 individuals were found in 34 quadrats. In both habitats, Z. arboreus was associated with downed wood. Other species occurring in more than $15 \%$ of quadrats in the Northern Red Oak - Large-toothed Aspen woodland were Strobilops labyrinthicus (Say, 1817), Glyphyalinia indentata (Say, 1823), and Euchemotrema fraternum (Say, 1824). Although a lower number and diversity of terrestrial snails in the conifer plantation was expected, the contrast was greater than anticipated. The estimated abundance of $46000 \mathrm{~N}$. ovalis per hectare suggests the potential importance of these medium-sized snails in the relatively dry Northern Red Oak - Large-toothed Aspen ecosystem.

Key Words: Terrestrial snails; land snails; Novisuccinea ovalis; Zonitoides arboreus; savannah; oak woodland; pine plantation; diversity; abundance; Constance Bay; Ontario

\section{Introduction}

At Constance Bay, Ontario, an open scrubby savannah of unusual composition (Catling and Brunton 2010; Catling et al. 2010) and with rare species followed two different succession paths. Some of it became a dry Northern Red Oak (Quercus rubra L.) - Large-toothed Aspen (Populus grandidentata Michx.) woodland (Figure 1a), a natural succession favoured in the case of fire suppression. The other path has been the unnatural conversion of the savannah to Red Pine (Pinus resinosa Aiton) plantation (Figure 1b), beginning with extensive planting of that species in the 1950s (Catling and Brunton 2010; Catling and Kostiuk 2010; Catling et al. 2010). The negative impact of pine plantations on biodiversity in native habitats has been studied in Canada for some groups of organisms, such as vascular plants and grasshoppers (Catling and Kostiuk 2010, 2015). Experimental removal of planted pine trees and pine needle litter at Constance Bay has successfully restored a portion of the savannah (Catling and Kostiuk 2010). Such restorations should be based on data concerning benefits to flora and fauna (Catling and Kostiuk 2010; Spitale 2011; Catling 2013).

The objective here was to determine the impact of plantation on terrestrial snails, by exploring the difference in snail assemblages in the two succession types after about 60 years. An added benefit is a contribution to better understanding of snail ecology and, particularly, the importance of snails in relatively dry ecosystems.

\section{Study Area}

The study area included lands in and near (within 1 $\mathrm{km})$ the Constance and Buckham's Bay Community Centre $\left(45.49944^{\circ} \mathrm{N}, 76.09325^{\circ} \mathrm{W}\right)$. The plantation was a pure stand of Red Pine without understory vascular plants but sometimes with a carpet of bryophytes. The Northern Red Oak - Large-toothed Aspen area included old, spreading Northern Red Oaks, as well as young oaks and young aspens; occasional dying Jack Pine (Pinus banksiana Lambert); persisting depauperate shrubs from an earlier period of more open conditions, including Early Lowbush Blueberry (Vaccinium angustifolium Aiton), Susquehana Sand Cherry (Prunus susquehanae Willdenow), Sweet-fern (Comptonia peregrina (L.) J. M. Coulter), Black Huckleberry (Gaylussacia baccata (Wangeheim) K. Koch), and Poison Ivy (Toxicodendron radicans (L.) Kuntz); herbs including Bracken Fern (Pteridium aquilinum (L.) K. Kuhn); and graminoids such as Canada Bluegrass (Poa compressa L.), Kentucky Bluegrass (Poa pratensis L.), and Dry-spike Sedge (Carex siccata Dewey).

A contribution towards the cost of this publication has been provided by the Thomas Manning Memorial Fund of the Ottawa Field-Naturalists' Club. 


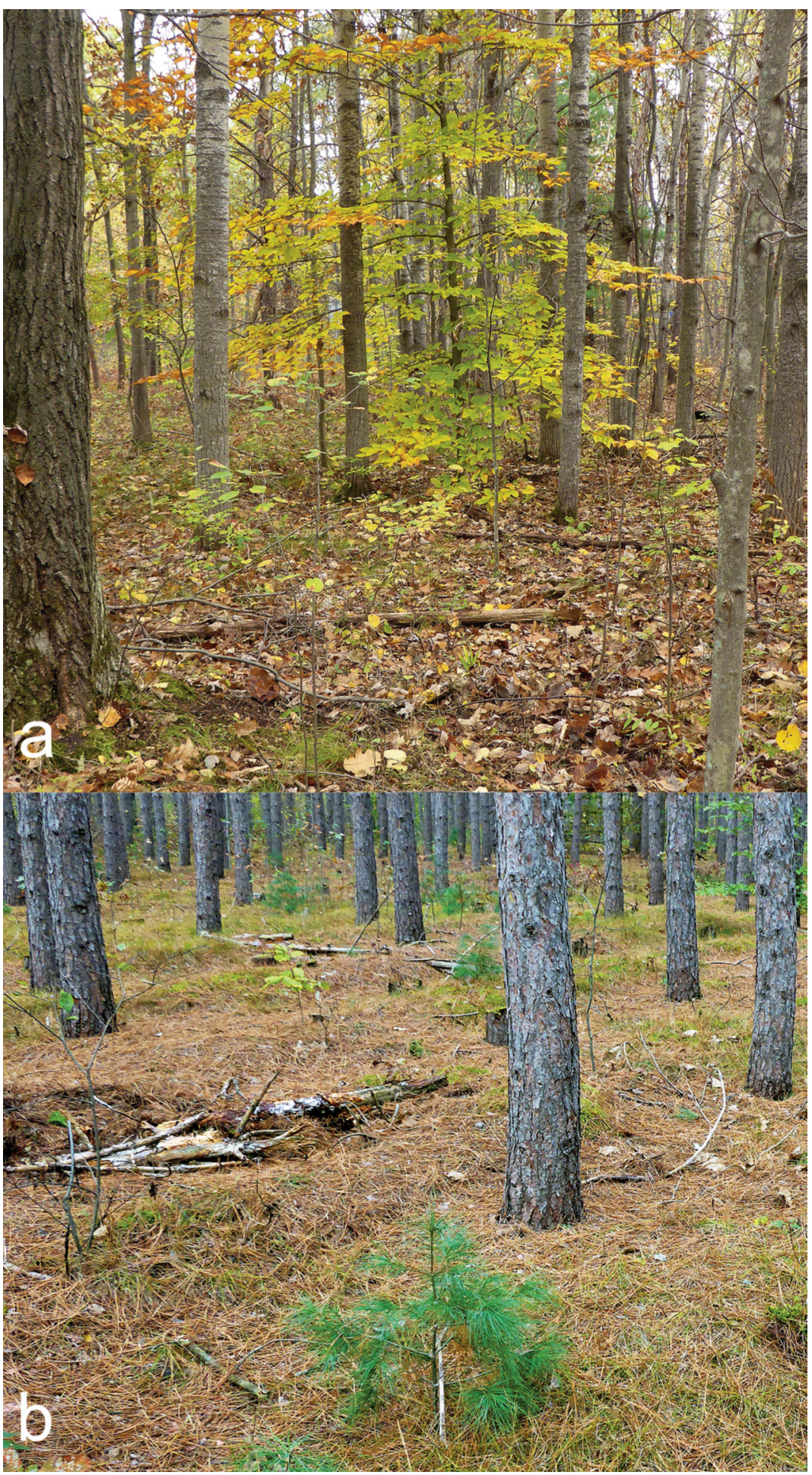

FiguRE 1. Constance Bay study area. a. Northern Red Oak (Quercus rubra) - Large-toothed Aspen (Populus grandidentata) woods. b. Approximately 60-year-old Red Pine (Pinus resinosa) plantation. Both habitats were scrub savannah approximately 60 years ago. Photos: P. M. Catling. 


\section{Methods}

\section{Data Collection}

Species of terrestrial snails and their numbers (both dead and alive) were recorded in ten $1-\mathrm{m}^{2}$ quadrats at 5-m intervals in 20 transects of which ten were in Red Pine plantation and ten were in Northern Red Oak Large-toothed Aspen woodland. Each quadrat was searched for 30 minutes. No minor adjustments were made to include woody debris or other potentially important microhabitat, but it was occasionally necessary to avoid trees. Usually, little was found after the first 20 minutes of searching; thus, 30 minutes was considered a sufficient amount of search time. Only visual handsearching was carried out. All leaf litter and the upper $2 \mathrm{~mm}$ of hard soil was searched. The survey was conducted during mild, $5-15^{\circ} \mathrm{C}$, clear weather in September 2014 before leaf fall. Transects were laid out in such a way as to avoid habitat edges and each other by at least $20 \mathrm{~m}$. They were parallel and $50 \mathrm{~m}$ in length. The approximate areas of available habitat within which the survey took place were 10.28 ha for the Northern Red Oak - Large-toothed Aspen woodland and 10.54 ha for the Red Pine plantation.

\section{Identification}

Specimens were collected for identification and vouchers identified by the authors were donated to the Canadian Museum of Nature with the assistance of curator Dr. Jean-Marc Gagnon. Living snails were placed in 70\% alcohol and, subsequently, dried for storage. Both living snails and empty shells were included in the study and were identified on the basis of shell characteristics using Pilsbry (1939, 1940, 1946, 1948), Burch (1962), and Grimm et al. (2010) as well as some recent monographs (e.g., Nekola and Coles 2010) and updates (e.g., Badra 2008; Forsyth and Oldham 2014; Nekola et al. 2015). The names of snails used here are taken from Grimm et al. (2010) despite some limitations of that work (Nekola 2010a).

\section{Results}

Manually searching a defined area, for a prescribed period has been considered an efficient method for estimating diversity and relative abundance of millipedes (Mesibov et al. 1995) and should work well for snails provided small species are not overlooked and they are not deep in the soil. Because many microsnails were recorded and few living snails were found in the upper $2 \mathrm{~mm}$ of harder soil, we think that the method was satisfactory for our purposes.

The identification of Novisuccinea ovalis (Say, 1817) is appropriate according to the way in which this group of snails is currently defined, although some authors have stressed the taxonomic difficulty of this group (Grimm et al. 2010). Other succineids, such as Catinella vermeta (Say, 1829), Oxyloma retusum (I. Lea, 1834), and Succinea putris (L., 1758), occur in this part of Ontario, but these are relatively distinctive genera of wetlands, shores, and disturbed habitats and differ in size, colour, and/or aperture shape.

The specimens of Helicodiscus had relatively broad whorls and a relatively deep umbilicus suggesting $H$. parallelus (Say, 1817) rather than $H$. shimeki Hubricht 1962. Strobilops shells clearly had five or six basal and parietal folds and, in a few shells where this could not be reliably evaluated, the spires were convex; thus, all were identified as Strobilops labyrinthicus (Say, 1817).

A few taxa identified with " $c f$." were listed that way because of either inadequate material or complexity of the group. The Euconulus are treated as fulvus on the basis of relatively weak spiral striae on the base of the shell, but this and other characteristics were found to be difficult to evaluate. Because they are few and only found in the red oak woods, the lack of a positive identification does not affect the comparison. The specimens of Pupilla muscorum (L., 1758) had shallow sutures unlike the recently described $P$. hudsonianum Nekola and Coles, 2015 (Nekola et al. 2015). The shells of Columella were immature.

In the Northern Red Oak - Large-toothed Aspen woodland, 13 species and 661 individuals were recorded, whereas in the Red Pine plantation both the number of species (six) and relative abundance ( 24 individuals) were much lower (Table 1). There was much variation among the quadrats: 85 contained no snails, whereas 36 snails including six species were found in the quadrat that contained the most snails.

The most abundant species in the Northern Red Oak - Large-toothed Aspen woodland was the succineid snail $N$. ovalis (Figure 2, family Succineidae), which was present in 74 of the 100 quadrats and was represented by 460 individuals. We estimated that there were 46000 of these snails per ha. The most common species in the Red Pine plantation was Zonitoides arboreus (Say, 1816), which was present in 16 quadrats and represented by 17 individuals. This species was the second most common in the Northern Red Oak - Largetoothed Aspen woodland where 70 individuals were found in 34 quadrats. In both habitats $Z$. arboreus was in or on rotting wood. Other species occurring in more than $15 \%$ of quadrats in the Northern Red Oak - Largetoothed Aspen woodland were Strobilops labyrinthicus, Glyphyalinia indentata (Say, 1823), and Euchemotrema fraternum (Say, 1824) (Table 1).

\section{Discussion}

What was a single scrub savannah habitat approximately 60 years ago diverged into two habitats: a planted conifer plantation and dry deciduous woodland. Ten examples of the conifer plantation differed from ten examples of the deciduous woodland in having less diversity and smaller numbers of terrestrial snails. The data suggest that the diversity and numbers of snails will decline when a savannah or dry deciduous woodland transforms into a conifer plantation. However, the snail fauna can likely be re-established by restoration of the 
TABLE 1. Occurrence and numbers of land snails found in $1001-\mathrm{m}^{2}$ quadrats in a Northern Red Oak (Quercus rubra) - Largetoothed Aspen (Populus grandidentata) woods and a Red Pine (Pinus resinosa) plantation at Constance Bay, Ontario.

\begin{tabular}{|c|c|c|c|c|}
\hline \multirow[b]{2}{*}{ Species } & \multicolumn{2}{|c|}{$\begin{array}{c}\text { Northern Red Oak - } \\
\text { Large-toothed Aspen woods }\end{array}$} & \multicolumn{2}{|c|}{$\begin{array}{l}\text { Red Pine } \\
\text { plantation }\end{array}$} \\
\hline & $\begin{array}{c}\text { No. } \\
\text { quadrats }\end{array}$ & $\begin{array}{c}\text { No. } \\
\text { individuals }\end{array}$ & $\begin{array}{c}\text { No. } \\
\text { quadrats }\end{array}$ & $\begin{array}{c}\text { No. } \\
\text { individuals }\end{array}$ \\
\hline Oval Ambersnail, Novisuccinea ovalis (Say, 1817) & 74 & 460 & 2 & 2 \\
\hline Quick Gloss, Zonitoides arboreus (Say, 1816) & 34 & 70 & 16 & 17 \\
\hline Maze Pinecone, Strobilops labyrinthicus (Say, 1817) & 18 & 33 & 1 & 1 \\
\hline Carved Glyph, Glyphyalinia indentata (Say, 1823) & 17 & 22 & 0 & 0 \\
\hline Upland Pillsnail, Euchemotrema fraternum (Say, 1824) & 15 & 22 & 0 & 0 \\
\hline Whitelip, Neohelix albolabris (Say, 1817) & 7 & 8 & 0 & 0 \\
\hline Immature Polygyridae & 7 & 7 & 1 & 1 \\
\hline Compound Coil, Helicodiscus parallelus (Say, 1817) & 6 & 6 & 0 & 0 \\
\hline Trumpet Vallonia, Vallonia parvula Sterki, 1893 & 4 & 4 & 0 & 0 \\
\hline Angular Disc, Discus catskillensis (Pilsbry, 1896) & 3 & 23 & 0 & 0 \\
\hline Brown Hive, Euconulus fulvus (Müller, 1774) & 2 & 2 & 2 & 2 \\
\hline Widespread Column, Pupilla cf. muscorum (L., 1758)* & 2 & 2 & 0 & 0 \\
\hline Bottleneck Snaggletooth, Gastrocopta contracta (Say, 1822) & 1 & 1 & 0 & 0 \\
\hline Comb Snaggletooth, Gastrocopta pentodon (Say, 1822) & 1 & 1 & 0 & 0 \\
\hline Grovesnail, Cepaea nemoralis (L., 1758)* & 0 & 0 & 1 & 1 \\
\hline Toothless Column, Columella cf. edentula (Draparnaud, 1805) & 0 & 0 & 1 & 1 \\
\hline Total & & 661 & & 25 \\
\hline
\end{tabular}

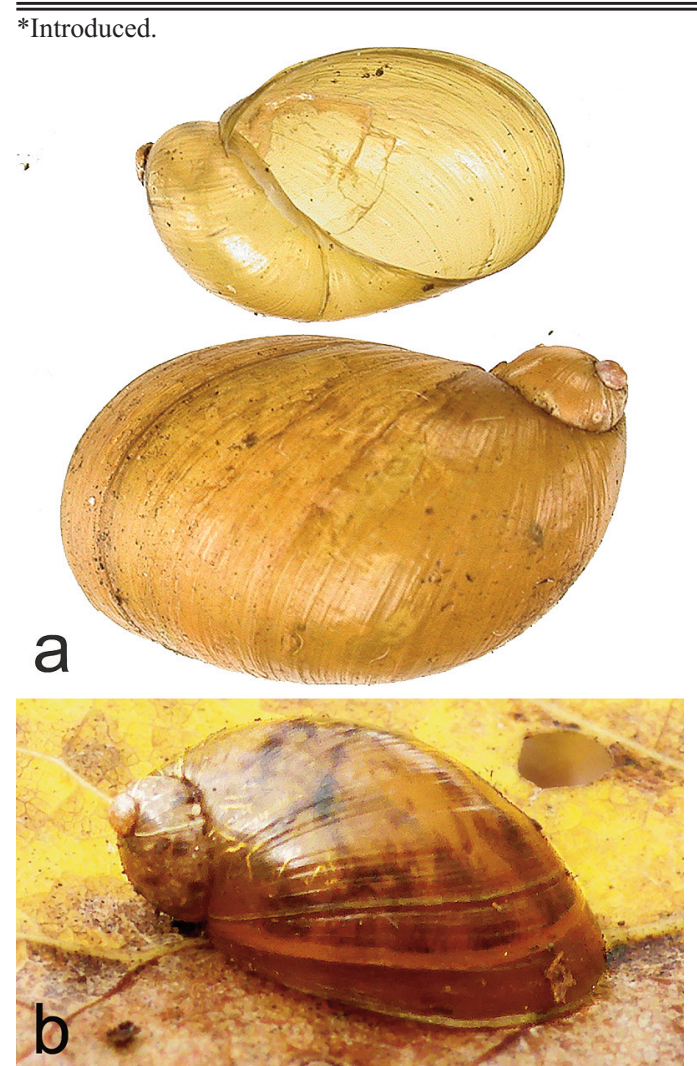

FIGURE 2. Oval Ambersnail (Novisuccinea ovalis (Say, 1917)), $10-15 \mathrm{~mm}$ in length, were common in the dry Northern Red Oak (Quercus rubra) - Large-toothed Aspen (Populus grandidentata) woods at Constance Bay with an estimated $46000 /$ ha. a. Shell with characteristic large aperture and few whorls. b. The animal below the transparent final whorl is blotched. Photos: P. M. Catling and B. Kostiuk. habitat, as in the case of other flora and fauna (Catling and Kostiuk 2010), leading to a diverse assemblage possibly dominated by the Oval Ambersnail, N. ovalis (Figure 2).

The small number of species and relative abundance of terrestrial snails in the conifer plantation was expected on the basis of numerous reports for both conifer forests and conifer plantations (Burch 1955; Karlin 1961; Solem 1984; Bonham et al. 2002; Jordan and Black 2012). A characteristic thick layer of pine needle litter occurred in the conifer plantation, but there was much less leaf litter in the dry deciduous woodland and areas of litter accumulation were localized. Downed wood was present in both habitats and substrate moisture appeared to be higher in the conifer plantation. The understory was generally much more extensive in the dry deciduous woodland. Any of these, and other differences, may account for differences in snail populations. The depressed terrestrial snail fauna associated with conifers is often accounted for by the high acidity of the needle duff and lack of decaying broadleaf vegetation (Nekola 2010b).

The habitat of $N$. ovalis is often dry, and this species can survive months of desiccation (Oughton 1948: 75); this snail may occur in large numbers after rain in dry woods (Latchford 1885: 229 sub Succinea obliqua). It is generally reported to be most common in upland woods and rock outcrops (Nekola 2003), but Pilsbry (1948: 804) reported it from both moist and dry ground, possibly based on more than one species. Although the Constance Bay habitat of periodically very dry, rolling, and elevated Northern Red Oak - Large-toothed Aspen woodland on well-drained sandy soil may seem to be an unlikely one for snails, $N$. ovalis was not uncommon there. The calculation of $46000 \mathrm{~N}$. ovalis per hectare in the dry deciduous woods draws attention to the potentially significant role of this medium-sized (adult length 
at this site $10-15 \mathrm{~mm}$ ) snail dispersed throughout the ecosystem ( $74 \%$ of quadrats) over an area of 10.28 ha.

\section{Literature Cited}

Badra, P. J. 2008. Special animal abstract for Euconulus alderi (a land snail). Michigan Natural Features Inventory, Lansing, Michigan, USA.

Bonham, K. J., R. Mesibov, and R. Bashford. 2002. Diversity and abundance of some ground-dwelling invertebrates in plantation vs. native forests in Tasmania, Australia. Forest Ecology and Management 158: 237-247. https://doi.org/ 10.1016/S0378-1127(00)00717-9

Burch, J. B. 1955. Some ecological factors of the soil affecting the distribution and abundance of land snails in eastern Virginia. Nautilus 69: 62-69.

Burch, J. B. 1962. How to Know the Eastern Land Snails. W. C. Brown, Dubuque, Iowa, USA. https://babel.hathitrust .org/cgi/pt?id=mdp.39076006431519; view=1up;seq=77.

Catling, P. M. 2013. The cult of the Red Pine - a useful reference for the over-afforestation period of Ontario. Canadian Field-Naturalist 127: 198-199. https://doi.org/10.22 621/cfn.v127i2.1462

Catling, P. M., and D. F. Brunton. 2010. Some notes on the biodiversity of the Constance Bay Sandhills. Trail \& Landscape 44: 123-130.

Catling, P. M., and B. Kostiuk. 2010. Successful re-establishment of a native savannah flora and fauna on the site of a former pine plantation at Constance Bay, Ottawa, Ontario. Canadian Field-Naturalist 124: 169. https://doi.org/10.22 621/cfn.v124i2.1056

Catling, P. M., and B. Kostiuk. 2015. Grasshopper outing contributes to Constance Bay Biothon. Trail \& Landscape 49: 103-113.

Catling, P. M., K. W. Spicer, and D. F. Brunton. 2010. The history of the Constance Bay Sandhills - decline of a biodiversity gem in the Ottawa valley. Trail \& Landscape 44: 106-122.

Forsyth, R. G., and M. J. Oldham. 2014. Distribution of Strobilops aeneus Pilsbry, 1926, in Canada, with two new Ontario records (Mollusca: Gastropoda: Strobilopsidae). Check List 10: 397-401. https://doi.org/10.15560/10.2.397

Grimm, F. W., R. G. Forsyth, F. W. Schueler, and A. Karstad. 2010. Identifying Land Snails and Slugs in Canada: Introduced Species and Native Genera. Canadian Food Inspection Agency, Ottawa, Ontario, Canada.

Jordan, S. F., and S. H. Black. 2012. Effects of forest land management on terrestrial mollusks: a literature review. Xerces Society for Invertebrate Conservation, Portland, Oregon, USA.

Karlin, E. J. 1961. Ecological relationships between vegetation and the distribution of land snails in Montana, Colorado and New Mexico. American Midland Naturalist 65: 60-66. https://doi.org/10.2307/2423002
Latchford, F. R. 1885. Observations on the terrestrial Mollusca of Ottawa and vicinity. Transactions of the Ottawa Field-Naturalists' Club 2: 211-231.

Mesibov, R., R. J. Taylor, and R. N. Brereton. 1995. Relative efficiency of pitfall trapping and hand-collecting from plots for sampling of millipedes. Biodiversity and Conservation 4: 429-439. https://doi.org/10.1007/BF00058426

Nekola, J. C. 2003. Terrestrial gastropod fauna of northeastern Wisconsin and the southern Upper Peninsula of Michigan. American Malacological Bulletin 18: 21-44. https:// doi.org/10.4003/006.028.0221

Nekola, J. C. 2010a. [Book Review] "Identifying Land Snails and Slugs in Canada" by F. Wayne Grimm et al. 2010. Canadian Field-Naturalist 124: 67-68. https://doi.org/10 $.22621 / \mathrm{cfn} . v 124 i 1.1042$

Nekola, J. C. 2010b. Acidophilic terrestrial gastropod communities of North America. Journal of Molluscan Studies 76: 144-156. https://doi.org/10.1093/mollus/eyp053

Nekola, J. C., and B. F. Coles. 2010. Pupillid land snails of eastern North America. American Malacological Bulletin 28: 29-57. https://doi.org/10.4003/006.028.0221

Nekola, J. C., B. F. Coles, and M. Horsák. 2015. Species assignment in Pupilla (Gastropoda: Pulmonata: Pupillidae) integration of DNA-sequence data and conchology. Journal of Molluscan Studies 81: 196-216. https://doi.org/10.1093 /mollus/eyu083

Oughton, J. 1948. A zoogeographical study of the land snails of Ontario. Biological series 57. University of Toronto Press, Toronto, Ontario, Canada.

Pilsbry, H. A. 1939. Land Mollusca of North America (North of Mexico). Volume 1, Part 1. Monograph 3. Academy of Natural Sciences of Philadelphia, Philadelphia, Pennsylvania, USA.

Pilsbry, H. A. 1940. Land Mollusca of North America (North of Mexico). Volume 1, Part 2. Monograph 3. Academy of Natural Sciences of Philadelphia, Philadelphia, Pennsylvania, USA.

Pilsbry, H. A. 1946. Land Mollusca of North America (North of Mexico). Volume 2, Part 1. Monograph 3. Academy of Natural Sciences of Philadelphia, Philadelphia, Pennsylvania, USA.

Pilsbry, H. A. 1948. Land Mollusca of North America (North of Mexico). Volume 2, Part 2. Monograph 3. Academy of Natural Sciences of Philadelphia, Philadelphia, Pennsylvania, USA.

Solem, A. 1984. A world model of land snail diversity and abundance. Pages 6-22 in World-wide Snails. Edited by A. Solem and A. C. van Bruggen. Brill/Backhuys, Leiden, Netherlands.

Spitale, S. P. 2011. Succession in the understory of Red Pine plantations in southern Ontario. M.Sc. thesis, University of Waterloo, Waterloo, Ontario, Canada.

Received 15 November 2015

Accepted 7 June 2017 